\title{
Binding and Metabolism of Platelet-activating Factor by Human Neutrophils
}

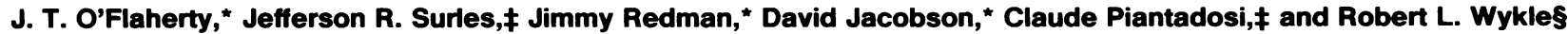 \\ *Department of Medicine and §Biochemistry, Wake Forest University Medical Center, Winston-Salem, \\ and $\ddagger$ Department of Medical Chemistry, University of North Carolina, Chapel Hill, North Carolina 27103
}

\begin{abstract}
Human polymorphonuclear neutrophils rapidly incorporated radiolabeled platelet-activating factor, 1-O-[hexadecyl-9, $\left.10-{ }^{3} \mathrm{H}_{2}\right]-$ 2-acetyl-sn-glycero-3-phosphocholine $\left.\left({ }^{3} \mathrm{H}\right] \mathrm{PAF}\right)$, and then metabolized it into its $s n-2$-fatty acyl derivative. Fractionation of radiolabel-pretreated cells over Percoll gradients revealed that virtually all of the intact $\left[{ }^{3} \mathrm{H}\right] \mathrm{PAF}$ was located in nongranule membranes that were enriched with alkaline phosphatase and cell surface glycoproteins. While still membrane associated, the ligand was rapidly converted to its acyl derivative and then more slowly transferred to specific granules and, to a lesser extent, azurophilic granules. In contrast, neutrophils did not metabolize $\left[{ }^{3} \mathrm{H}\right] \mathrm{PAF}$ at $4^{\circ} \mathrm{C}$ but rather gradually accumulated it in their alkaline phosphatase-enriched membrane subfractions. These same subfractions contained receptors for the ligand, as determined by their capacity to bind $\left[{ }^{3} \mathrm{H}\right] \mathrm{PAF}$ specifically. Binding was readily saturated, partially reversible, and fit a two receptor model; dissociation constant $\left(K_{d}\right)$ values for high and low affinity sites were 0.2 and $500 \mathrm{nM}$, respectively. Receptors with similar affinities were detected in whole cells. Furthermore, the potencies of several structural analogues in inhibiting binding of $\left.{ }^{3} \mathbf{H}\right]$ PAF to membranes correlated closely with their respective potencies in stimulating degranulation responses. Finally, quantitative studies suggested all or most of the cell's receptors were membrane associated. We conclude that PAF rapidly enters cellular membranes to bind with specific receptors that trigger function. The intramembranous ligand is also deacetylated, acylated, and then transferred to granules. This metabolism may be sufficiently rapid to limit ligand-receptor binding and distort quantitative analyses of receptors.
\end{abstract}

\section{Introduction}

Platelet-activating factor (PAF) ${ }^{1}$ is a sn-glycero-3-phosphocholine (GPC) derivative. At position 1, it is ether linked to a long chain

Address reprint requests to Dr. O'Flaherty.

Received for publication 24 January 1986 and in revised form 17 March 1986.

1. Abbreviations used in this paper: GPC, sn-glycero-3-phosphocholine; HPLC, high performance liquid chromatography; LDH, lactate dehydrogenase; homocholine-PAF, rac-1-O-hexadecyl-2-acetyl-glycero-3phosphohomocholine; lyso-PAF, deacetylated derivative of PAF; PMN, polymorphonuclear neutrophil; PAF, 1-O-alkyl-2-acetyl-sn-glycero-3phosphocholine; $\left[{ }^{3} \mathrm{H}\right] \mathrm{PAF}, 1-O$-hexadecyl-9, $10-\left[{ }^{3} \mathrm{H}_{2}\right]-2$-acetyl-sn-glycero3-phosphocholine; PC, diacylglycerophosphocholine; TLC, thin-layer chromatography; triethyl-PAF, rac-1-O-hexadecyl-2-acetyl-glycero-3phospho- $N^{\prime}, N^{\prime}, N^{\prime}$-triethylethanolamine.

J. Clin. Invest.

(C) The American Society for Clinical Investigation, Inc.

0021-9738/86/08/0381/08 \$1.00

Volume 78, August 1986, 381-388 fatty alcohol; at position 2 , it is esterified to acetic acid (1-3). Platelets, polymorphonuclear neutrophils (PMN), monocytes, macrophages, and endothelium produce PAF when stimulated (4-15). These cells can also inactivate the phospholipid, principally by deacetylating it and transferring a long chain fatty acid into the vacated 2-position (16-20). PAF activates platelets $(1,3,21), \operatorname{PMN}(22,23)$, macrophages (24), and smooth muscle $(25,26)$ in vitro; it causes anaphylactoid reactions when infused intravenously $(22,27,28)$ and induces the local accumulation of leukocytes when injected subcutaneously (29). PAF thus may be a natural mediator of inflammatory, allergic, thrombotic, and shock reactions. The mechanism by which PAF activates target cells is of interest. Based on the phospholipids striking biological potency, its stereospecificity, and its ability to desensitize target cells, we suggested that cellular receptors were involved in transducing bioactivity (30-32). Subsequent studies have indeed demonstrated specific binding sites for PAF in or on platelets, $\mathrm{PMN}$, and smooth muscle-containing tissues (33-36) while other studies have identified compounds that competitively inhibit PAF binding and bioactions (37-39). In this report, we examine PAF metabolism concurrently with binding, track the subcellular movement of PAF and its metabolites, and characterize the location of PAF receptors.

\section{Methods}

Reagents and buffers. The following were purchased from Sigma Chemical Co., St. Louis, MO: PIPES, type II bovine serum albumin (BSA), cytochalasin B, 2-mercaptoethanol, diisopropylfluorophosphate, phenylmethylsulfonylfluoride, type IV cytochrome $c$, and ATP. Percoll (Pharmacia Fine Chemicals, Uppsala, Sweden); $\left[{ }^{3} \mathrm{H}\right]$ concanavalin A (50 $\mathrm{Ci} / \mathrm{mmol}$ ) (New England Nuclear, Boston, MA); diacylglycerophosphocholine (PC) (Serdary Research Labs., London, Ontario, Canada); BudgetSolve (Research Products International Corp., Mount Prospect, IL); GF/ $\mathrm{C}$ glass microfiber filters (Whatman, Ltd., Maidstone, England); ethyl ether and high performance liquid chromatography (HPLC) grade methanol and chloroform (Fisher Scientific, Fair Lawn, NJ); and 0.25 $\mathrm{cm}$ silica gel thin layer chromatography (TLC) plates (Analtech, Inc. Newark, DE) (plates were preheated at $180^{\circ} \mathrm{C}$ for $3 \mathrm{~h}$ before use) were purchased from the indicated vendors. Binding and degranulation assays were performed in a modified Hanks' balanced salt solution $(1.4 \mathrm{mM}$ calcium chloride, $0.7 \mathrm{mM}$ magnesium chloride, $\mathrm{pH}$ 7.4) (30). Cells were disrupted in a relaxation buffer containing (mM): $\mathrm{KCl}(100), \mathrm{NaCl}(3)$, ATP (1), $\mathrm{MgCl}_{2}$ (3.5), and PIPES (10) (pH 7.3) (40).

Preparation of lipids. Deacetylated PAF (lyso-PAF) and unlabeled PAF were prepared from beef heart plasmalogens $(30)$. $\left[{ }^{3} \mathrm{H}\right] \mathrm{PAF}$ was prepared from synthetic 1-O-hexadec-9,10-enyl-2-lyso-GPC (natural isomer) (41) by reduction with tritium gas and acetylation of product (sp act, $56 \mathrm{Ci} / \mathrm{mmol}$ ) (42). rac-1-O-Hexadecyl-2-acetyl-glycero-3-phosphohomocholine (homocholine-PAF) and rac-1-O-hexadecyl-2-acetylglycero-3-phospho- $N^{\prime}, N^{\prime}, N^{\prime}$-triethylethanolamine (triethyl-PAF) were synthesized by procedures to be reported elsewhere. Lipid structures and purity $(>95 \%$ ) were determined in several TLC systems and by susceptibility to degradation with phospholipases $\mathrm{C}$ and $\mathrm{A}_{2}$, elemental analyses, nuclear magnetic resonance, and mass spectrometry (the last two analyses were done only on unlabeled compounds). The lipids were stored at 
$-70^{\circ} \mathrm{C}$ in methanol/chloroform $(2: 1, \mathrm{vol} / \mathrm{vol})$. Before use, they were freed of organic solvents under a stream of nitrogen and taken up in Hanks' buffer containing BSA $(2.5 \mathrm{mg} / \mathrm{ml})$.

Degranulation assay. Human leukocytes (1.3 million; >95\% PMN) were suspended in $0.5 \mathrm{ml} \mathrm{Hanks'} \mathrm{buffer;} \mathrm{incubated} \mathrm{at} 37^{\circ} \mathrm{C}$ for $20 \mathrm{~min}$; treated with cytochalasin B $(2.5 \mu \mathrm{g})$ for $2-4 \mathrm{~min}$; challenged for $5 \mathrm{~min}$; placed on ice; and centrifuged $\left(400 \mathrm{~g}, \times 4 \mathrm{~min}, 4^{\circ} \mathrm{C}\right)$ to obtain supernatant fluid that was assayed for lysozyme, $\beta$-glucuronidase, and lactate dehydrogenase (LDH) (30). Results are reported as net enzyme release; i.e., the percentage of total cellular enzyme released by challenged cells minus that released by identically treated but unchallenged cells. In the various studies, no release of cytosolic LDH was detected indicating that release of granule-bound enzymes (lysozyme and $\beta$-glucuronidase) reflected degranulation rather than cell lysis.

$P M N$ fractionation. $4 \times 10^{8}$ PMN were isolated from human blood, suspended in relaxation buffer $(14 \mathrm{ml})$, nitrogen cavitated, and centrifuged to remove nuclei and undisrupted cells. The postnuclear suspension was fractionated over Percoll discontinuous gradients $(40,43,44)$. Fractions $(1.9 \mathrm{ml})$ from these gradients were removed with a peristaltic pump. In some studies, $4 \times 10^{8} \mathrm{PMN}$ were incubated with $200 \mathrm{pM}\left[{ }^{3} \mathrm{H}\right] \mathrm{PAF}$ in 7 $\mathrm{ml}$ of Hanks' buffer $(250 \mu \mathrm{g} / \mathrm{ml} \mathrm{BSA})$ at $37^{\circ} \mathrm{C}$ for an indicated interval. The incubation was stopped by adding $35 \mathrm{ml}$ of Hanks' buffer $\left(4^{\circ} \mathrm{C}\right)$, centrifuged, washed once with $42 \mathrm{ml}$ of Hanks' buffer $\left(4^{\circ} \mathrm{C}\right)$, rewashed with $42 \mathrm{ml}$ of relaxation buffer, and resuspended in $7 \mathrm{ml}$ of relaxative buffer. Suspensions were then nitrogen cavitated, centrifuged to remove undisrupted cells and nuclei, and fractionated. In these studies, $>80 \%$ of the initially added radiolabel was located in cells following the last wash. For some studies, disrupted PMN were fractionated and fractions enriched with the marker enzyme for membranes, alkaline phosphatase, were pooled, diluted in a Percoll-enriched dilution buffer (13.2 Percoll; $0.3 \mathrm{ml}$ water, $1.5 \mathrm{ml}$ dilution buffer $[40,43])$, and centrifuged $(140,000$ $\left.g, \times 2 \mathrm{~h}, 4^{\circ} \mathrm{C}\right)(43)$. The supernatant fluid was removed and the pelleted membranes were gently resuspended in Hanks' buffer before storing at $4^{\circ} \mathrm{C}$.

Binding assay. $1 \times 10^{7}$ PMN, $200 \mu \mathrm{l}$ of a fraction from Percoll gradients (to which $4 \mathrm{mM}$ calcium chloride was added to offset the presence of calcium chelators), or $50 \mu \mathrm{l}$ of isolated membranes was suspended with a final volume of $0.9 \mathrm{ml}$ Hanks' buffer in a $1.5-\mathrm{ml}$ conical polyethylene microcentrifuge tube (Brinkmann Instruments, Inc., Westbury, NY). Suspensions were then simultaneously exposed to $\left[{ }^{3} \mathrm{H}\right] \mathrm{PAF}(50 \mu \mathrm{l}$ in Hanks' buffer containing BSA) plus unlabeled PAF ( $50 \mu$ l in BSAHanks' buffer) or BSA-Hanks' buffer $(50 \mu l)$. Unless otherwise specified, all studies were performed at $4^{\circ} \mathrm{C}$ in a final volume of $1 \mathrm{ml}$ containing $250 \mu \mathrm{g} \mathrm{BSA}, 1.4 \mathrm{mM} \mathrm{Ca}^{2+}$, and $0.7 \mathrm{mM} \mathrm{Mg}^{2+}$. Following incubation for indicated periods, suspensions were suctioned through premoistened GF/C filters. The microfuge tubes were washed five times with $1.5 \mathrm{ml}$ of Hanks' buffer $\left(4^{\circ} \mathrm{C}\right)$ and each wash was suctioned through the same filter. Filters were air dried, placed in the bottom of 10 -ml plastic vials, overlaid with $1 \mathrm{ml}$ of methanol for $5 \mathrm{~min}$, and mixed with $7 \mathrm{ml}$ of Budget-Solve. Vials were counted for 4 min with a Beckman LS 1801 scintillation counter (Research Products International Corp., Mt. Prospect, IL). The system was programmed to measure each sample's quench and extrapolate from counts per minute to disintegrations per minute using tritium standards. We determined that the washed microfuge tubes contained essentially none of the originally added $\left[{ }^{3} \mathrm{H}\right] \mathrm{PAF}$. However, GF/C filters retained $\sim 2 \%$ of applied tritium. This fractional retention appeared independent of: (a) the amount of applied [ $\left.{ }^{3} \mathrm{H}\right] \mathrm{PAF}(20 \mathrm{fmol}$ to $2 \mathrm{pmol}) ;(b)$ the presence of cells or subcellular fractions in the filtrate; and $(c)$ the presence of excess PAF ( $20 \mathrm{fmol}$ to $200 \mathrm{pmol})$. Filter binding, therefore, had the attributes of a nonspecific, unsaturable binding site. To correct for filter retention of radiolabel, all test samples were paired with an identically treated control sample that lacked PMN, cell fractions, or membranes. Binding was then defined as the difference between the disintegrations per minute retained by filters loaded with test and control samples. In paired samples that were incubated with $200 \mathrm{pM}\left[{ }^{3} \mathrm{H}\right] \mathrm{PAF}$, for instance, this involved subtracting $\sim 400-800 \mathrm{dpm}$ (for control samples) from 1,000 to $3,000 \mathrm{dpm}$ (for test samples). The resulting value, which we call bound $\left[{ }^{3} \mathrm{H}\right] \mathrm{PAF}$, was corrected for the bound $\left[{ }^{3} \mathrm{H}\right] \mathrm{PAF}$ in tandem assays of test and control samples containing excess PAF ( 10 to $100 \mathrm{nM})$ to obtain specifically bound $\left[^{3} \mathrm{H}\right] \mathrm{PAF}$. Specific binding, therefore, represents the amount of binding that was saturable; at $20 \mathrm{pM}$ of $\left[{ }^{3} \mathrm{H}\right] \mathrm{PAF}$, this was $\sim 70 \%$ of bound tritium.

Scatchard analyses plotted femtomole bound/femtomole free ratios of PAF in test samples (minus control samples) containing 20,63.2, or $200 \mathrm{pM}\left[{ }^{3} \mathrm{H}\right] \mathrm{PAF}$ plus increasing amounts of unlabeled PAF. The data fit a two-receptor model, as described elsewhere (33-35). The low affinity binding sites were fit to a straight line by the method of least squares using data obtained at high ligand concentrations, i.e., 6.3, 20,63.2, and $200 \mathrm{nM}$ of unlabeled PAF plus [ $\left.{ }^{3} \mathrm{H}\right] \mathrm{PAF}$. For both whole cells and their membrane fractions, correlation coefficients of linearity were $\sim 0.99$. The amounts of PAF bound to the low affinity receptors at low ligand concentrations (i.e., 2, 0.6, 0.2, 0.06, $0.02 \mathrm{nM}$ of unlabeled PAF $\left.+\left[{ }^{3} \mathrm{H}\right] \mathrm{PAF}\right)$ were estimated with the following formula (44-46): $[R L]$ $=R_{t}[L] /\left(K_{d}+[L]\right)$, where $[R L]$ is femtomoles of PAF bound to the low affinity receptors at [L] concentration of free PAF and $K_{d}$ and $R_{\mathrm{t}}$ are the respective affinity constants and total receptor numbers for low affinity receptors. These latter two values were 150 and $2.9 \mathrm{nmol} /$ liter for whole cells and 560 and $18.8 \mathrm{nmol} /$ liter for membranes. At each low concentration of PAF (i.e., 0.02-2 nM), the estimated amount of PAF bound to the low affinity receptors was subtracted from total bound PAF to obtain the amount of PAF bound to high affinity receptors. Bound/free ratios were derived using this latter estimate for bound ligand. Our studies assumed that PAF bound to the low affinity receptor was in equilibrium with the high affinity receptor. The resulting data were fit to a straight line (correlation coefficients $>0.9$ ) by the method of least squares.

$\left.{ }^{3} \mathrm{H}\right]$ Concanavalin A labeling. $4 \times 10^{8} \mathrm{PMN}$ in $50 \mathrm{ml}$ of Hanks' buffer $\left(\mathrm{no} \mathrm{Ca}^{2+}\right.$ or $\left.\mathrm{Mg}^{2+}\right)$ were incubated with $1 \mathrm{nM}\left[{ }^{3} \mathrm{H}\right]$ concanavalin A at $20^{\circ} \mathrm{C}$ for $20 \mathrm{~min}$, diluted further with $50 \mathrm{ml}$ of Hanks' buffer $\left(4^{\circ} \mathrm{C}\right)$, chilled to $4^{\circ} \mathrm{C}$, washed with $50 \mathrm{ml}$ of Hanks' buffer $\left(4^{\circ} \mathrm{C}\right)$ and then 50 $\mathrm{ml}$ of relaxation buffer $\left(4^{\circ} \mathrm{C}\right)$. Cells were suspended in $7 \mathrm{ml}$ of relaxation buffer before cavitating and fractionating, as described above.

$\left[{ }^{3} \mathrm{H}\right] \mathrm{PAF}$ metabolism. $1 \times 10^{7} \mathrm{PMN}$ were incubated in a final volume of $1 \mathrm{ml}$ with Hanks' buffer, $\left.200 \mathrm{pM} \mathrm{[}{ }^{3} \mathrm{H}\right] \mathrm{PAF}$ ( $\pm 10 \mathrm{~nm}$ PAF), and 250 $\mu \mathrm{g}$ BSA. Following a specified interval, suspensions were centrifuged $(16,000 \mathrm{~g}, \times 5 \mathrm{~s})$. Pelleted cells were washed twice in Hanks' buffer $\left(4^{\circ} \mathrm{C}\right)$. Cells and pooled supernatant fluids were then separately extracted with $1.6 \mathrm{ml}$ of methanol:chloroform $(1: 1, \mathrm{vol} / \mathrm{vol})$ and, after isolation of the chloroform layers, extracted $\times 2$ with $0.8 \mathrm{ml}$ of chloroform. The procedure always recovered $>95 \%$ of radioactivity in the pooled chloroform layers. Material was spotted on TLC plates and developed with chloroform/methanol/acetic acid/water (50:25:8:4; vol/vol). Strips $(0.5 \mathrm{~cm})$ of silica gel were sequentially scraped from the plates, overlaid with $1 \mathrm{ml}$ of methanol, mixed with $7 \mathrm{ml}$ of Budget-Solve, and measured for radioactivity as described above.

Subcellular marker assays. LDH, alkaline phosphatase, lysozyme, vitamin B-12 binding protein, myeloperoxidase, and $\beta$-glucuronidase were assayed as described (43). In assays of NADPH: cytochrome $c$ reductase, $100 \mu \mathrm{l}$ of a test sample were incubated with $1.6 \mathrm{mM}$ cytochrome c, $1.5 \mathrm{mM}$ NADPH, $2 \mathrm{mM} \mathrm{KCN}$, and $1 \%$ Tween 80 in a final volume of $1 \mathrm{ml}$ of $0.250 \mathrm{M}$ potassium phosphate buffer ( $\mathrm{pH}$ 7.7). Results are reported in nanomoles of cytochrome $c$ produced per minute, assuming an extinction coefficient of $27,700 \mathrm{mM} / \mathrm{ml}$ for the difference between oxidized and reduced cytochrome $c$ at $550 \mathrm{~nm}$. Protein was measured as described (31).

\section{Results}

Uptake of $\left[{ }^{3} \mathrm{H}\right] P A F$. PMN suspensions were incubated at $37^{\circ} \mathrm{C}$ with $\left.200 \mathrm{pM} \mathrm{[}{ }^{3} \mathrm{H}\right] \mathrm{PAF}$, centrifuged, and twice washed with $4^{\circ} \mathrm{C}$ buffer. After 2.5-, 5-, 10-, 20-, and 60-min incubations, the cells incorporated $79,83,89,93$, and $95 \%$ of initially added radioactivity. This uptake was $72,85,95,97$, and $97 \%$, respectively, in the presence of $10 \mathrm{nM}$ PAF. Contrastingly, at $4^{\circ} \mathrm{C}$, cellular uptake of $\left[{ }^{3} \mathrm{H}\right]$ PAF proceeded much more slowly, peaked at $\leqq 18 \%$ of added radiolabel and was appreciably reduced in the 
presence of $10 \mathrm{nM}$ PAF (Fig. 1). These results are compatible with the view that $\left[{ }^{3} \mathrm{H}\right] \mathrm{PAF}$ enters two different cellular pools. One of these has a high capacity (i.e., is relatively unsaturable) for handling ligand at physiological temperatures. The second pool is readily saturated but evident only at temperatures that block ligand accumulation in the high capacity pool.

Metabolism of $\left[{ }^{3} H\right] P A F$. After incubation with ligand, PMN and their extracellular fluid were isolated, separately extracted, and analyzed on TLC. Fig. 2 gives the distribution of radioactivity on TLC plates loaded with extracts from the cells or extracellular fluid of suspensions incubated with $200 \mathrm{pM}\left[{ }^{3} \mathrm{H}\right] \mathrm{PAF}$ for $60 \mathrm{~min}$ at $37^{\circ} \mathrm{C}$ or $4^{\circ} \mathrm{C}$ (upper and lower panels, respectively). At $37^{\circ} \mathrm{C}$, virtually all radioactivity was cell associated and comigrated with PC standard; at $4^{\circ} \mathrm{C}$, all radioactivity comigrated with PAF and only $17 \%$ was cell associated. Based on our previous studies (17), material migrating with $\mathrm{PC}$ is $1-O$ [hexadecyl-9,10- $\left.{ }^{3} \mathrm{H}_{2}\right]-2$-fatty acyl-GPC. The kinetics of $\left[{ }^{3} \mathrm{H}\right] \mathrm{PAF}$ conversion to this fatty acylated derivative at $37^{\circ} \mathrm{C}$ are given in Fig. 3. The upper panel reports on results with cells incubated with $200 \mathrm{pM}\left[{ }^{3} \mathrm{H}\right] \mathrm{PAF}$; data in the lower panel are for cells incubated with the radioactive ligand plus $10 \mathrm{nM}$ unlabeled PAF. Under both conditions, radiolabel rapidly ( $\mathrm{t}^{1 / 2} \sim 1$ to $2 \mathrm{~min}$ ) disappeared from the extracellular fluid, briefly appeared in cells as intact $\left[{ }^{3} \mathrm{H}\right] \mathrm{PAF}$ (i.e., material comigrating with PAF), and progressively accumulated as a cellular species comigrating with PC. At all time points,

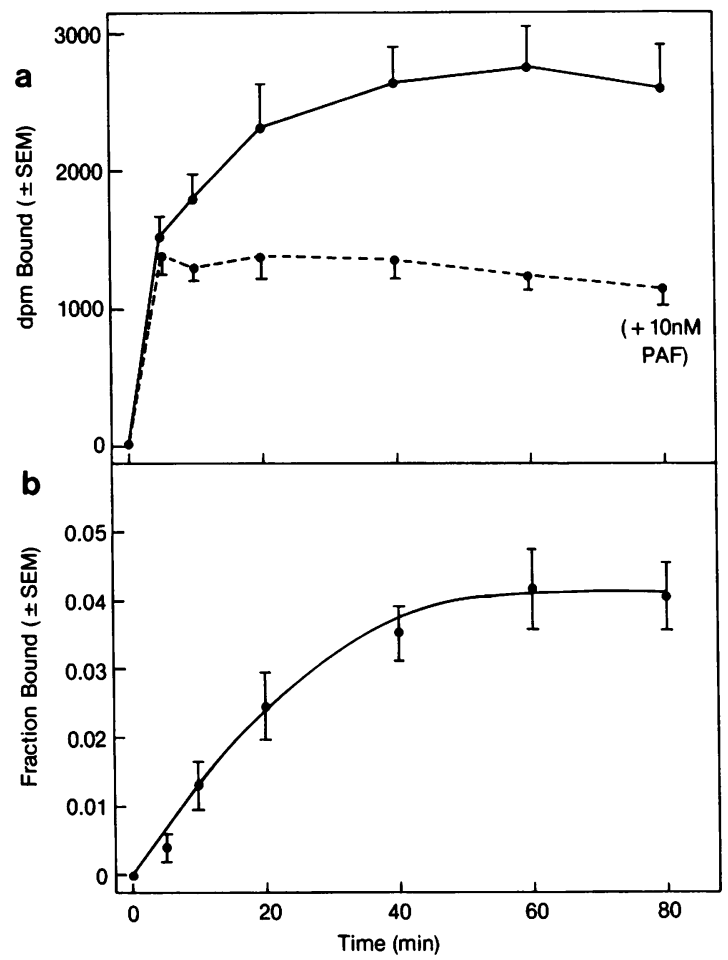

Figure 1. Binding of $\left[{ }^{3} \mathrm{H}\right] \mathrm{PAF}$ to neutrophils at $4^{\circ} \mathrm{C} .1 \times 10^{7} \mathrm{PMN}$ in $1 \mathrm{ml}$ of Hanks' buffer were incubated with $\left[{ }^{3} \mathrm{H}\right] \mathrm{PAF}(200 \mathrm{pM})$ for the indicated interval and then assayed for uptake of radiolabel by filtration techniques. (a) Cell bound radioactivity is given in $\mathrm{dpm}$ in the absence (-) or presence (- - ) of 10 nM PAF. (b) Fraction of total $\left[{ }^{3} \mathrm{H}\right] \mathrm{PAF}$ specifically bound to cells is plotted. Specific binding was the difference between binding found in the absence and presence of excess PAF; this parameter increased linearly between $2.5 \times 10^{6}$ and 2.5 $\times 10^{7} \mathrm{PMN} / \mathrm{ml}$. Each point is the mean of experiments done on eight different donor cell preparations.

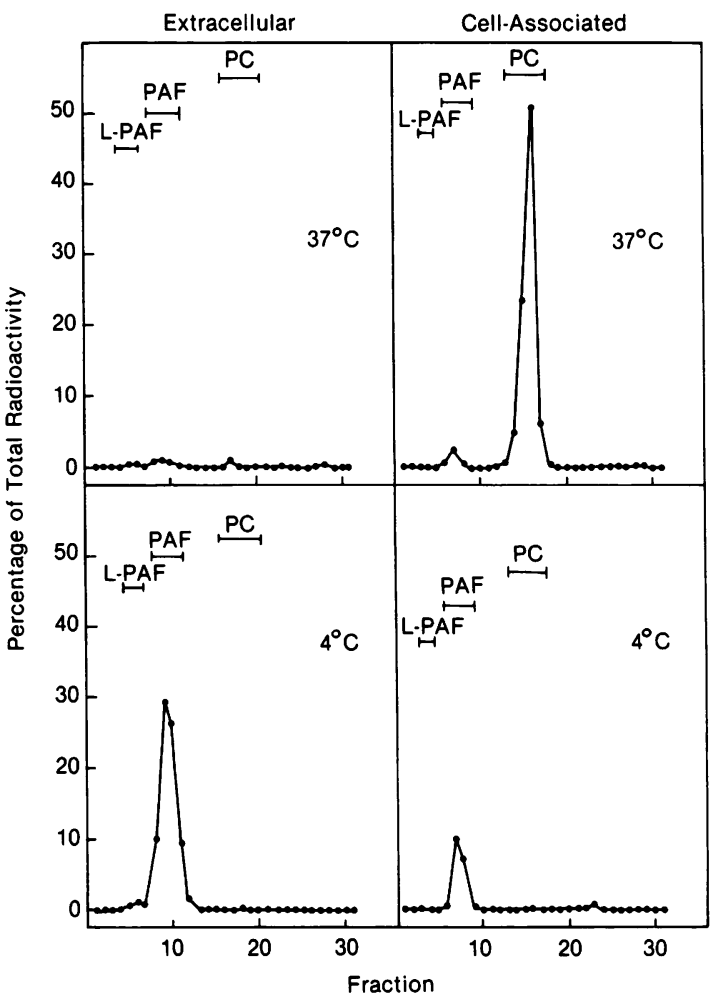

Figure 2. Temperature dependency of $\left[{ }^{3} \mathrm{H}\right] \mathrm{PAF}$ metabolism. $1 \times 10^{7}$ PMN in $1 \mathrm{ml}$ of Hanks' buffer were incubated with $200 \mathrm{pM}\left[{ }^{3} \mathrm{H}\right] \mathrm{PAF}$ for $60 \mathrm{~min}$ at $37^{\circ} \mathrm{C}$ (upper panels) or $4^{\circ} \mathrm{C}$ (lower panel). Suspensions were separated into cells and extracellular fluid (see Methods) that were separately extracted and analyzed on TLC. Results are reported as percentage of total radioactivity (i.e., extracellular plus cell-associated radioactivity applied to TLC plates) that was found in successive $0.5-\mathrm{cm}$ zones of TLC plates. Material was spotted between zones 1 and 2 . These results are typical of studies done on four different donor cell preparations.

$<2 \%$ of radioactivity migrated with lyso-PAF. Excess PAF appeared to enhance the speed with which intact $\left[{ }^{3} \mathrm{H}\right] \mathrm{PAF}$ was converted into material migrating with PC. These results help identify the two previously discussed pools: the high capacity, temperature-sensitive pool appears to include $\left[{ }^{3} \mathrm{H}\right] \mathrm{PAF}$ and its metabolites; the low capacity, temperature insensitive pool, presumably, is intact, cell-associated ligand.

Subcellular localization of radioactivity. $4 \times 10^{8} \mathrm{PMN}$ in 7 $\mathrm{ml}$ of Hanks' buffer were incubated with $200 \mathrm{pM}\left[{ }^{3} \mathrm{H}\right] \mathrm{PAF}$, washed with and suspended in relaxation buffer $\left(4^{\circ} \mathrm{C}\right)$. After nitrogen cavitation and removal of undisrupted cells, the preparation was centrifuged over Percoll gradients to obtain fractions enriched with markers for cytosol (LDH; fractions 1-4); membranes (alkaline phosphatase and $\left[{ }^{3} \mathrm{H}\right]$ concanavalin $A$ binding sites; fractions 5-9); specific granules (lysozyme, vitamin B-12 binding protein; fractions 11-15); and azurophilic granules ( $\beta$ glucuronidase, myeloperoxidase; fractions 17-20). The endoplasmic reticulum marker $(44,47)$, NADPH: cytochrome $c$ reductase, was distributed in decreasing amounts throughout the upper half of the gradients (refer to Figs. 5 and 7). Fig. 4 gives the distribution of total, $\left[{ }^{3} \mathrm{H}\right] \mathrm{PAF}$, and 1-O-[hexadecyl-9, $10^{3}$ $\mathrm{H}_{2}$ ]-2-fatty acyl-GPC in cells pretreated with $\left[{ }^{3} \mathrm{H}\right] \mathrm{PAF}$ for 5,20 , or $60 \mathrm{~min}$. Intact $\left[{ }^{3} \mathrm{H}\right] \mathrm{PAF}$ was always restricted to alkaline phosphatase-enriched fractions; $1-O-\left[\right.$ hexadecyl-9, $\left.10-{ }^{3} \mathrm{H}\right]-2$-fatty 


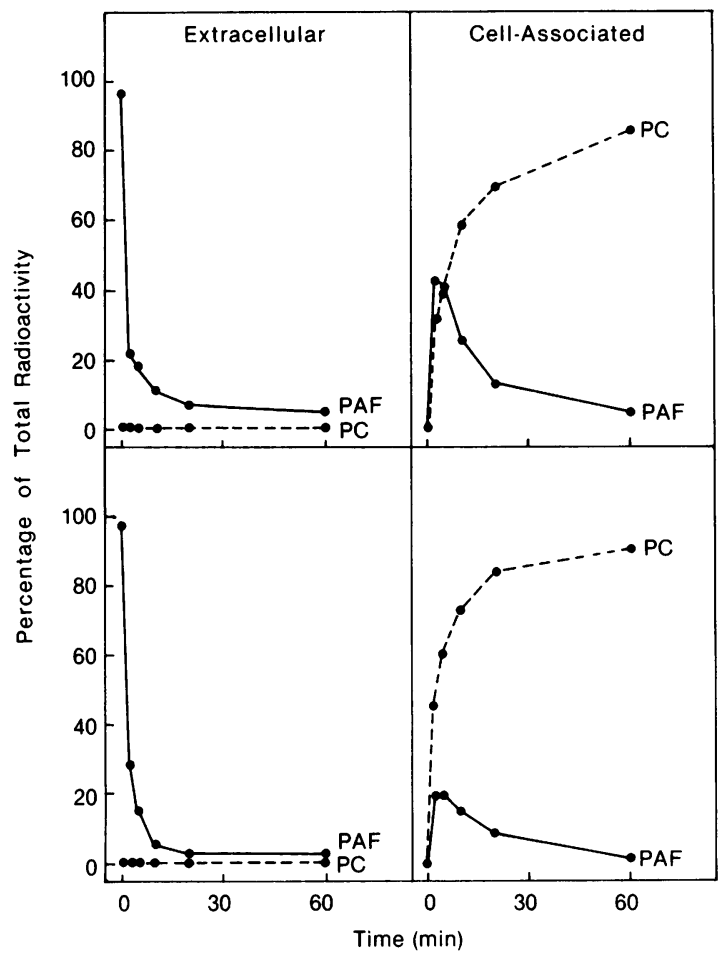

Figure 3. Kinetics of $\left[{ }^{3} \mathrm{H}\right] \mathrm{PAF}$ metabolism. Studies were performed as described in Fig. 2 on cells that were incubated at $37^{\circ} \mathrm{C}$ for the indicated time in the absence (upper panels) or presence (lower panels) of $10 \mathrm{nM}$ PAF. Results are reported as percentage of total (extracellular plus cell-associated) radioactivity applied to TLC plates that comigrated with PAF or PC. $<2 \%$ of radioactivity migrated with lyso-PAF. Each point is the mean of studies done on three different donor cell preparations.

acyl-GPC peaked in these fractions but also was associated with specific granules and, to a lesser extent, azurophilic granules; the amount of intact $\left.{ }^{3} \mathrm{H}\right] \mathrm{PAF}$ decreased with time whereas the fatty acyl derivative of $\left[{ }^{3} \mathrm{H}\right]$ PAF progressively accumulated and shifted from membrane to granule fractions. In contrast all cellassociated radioactivity ( $\sim 12 \%$ of total added radioactivity) in experiments with cells incubated at $4^{\circ} \mathrm{C}$ for 60 min was membrane-associated and consisted of intact $\left[{ }^{3} \mathrm{H}\right] \mathrm{PAF}$ (Fig.5). These results complement those reported in Figs. 2 and 3. They further suggest that the high capacity, temperature sensitive pool of radioactivity is principally membrane- and granule-associated acylated ligand while the second pool is membranous $\left[{ }^{3} \mathrm{H}\right] \mathrm{PAF}$.

Binding of $\left[{ }^{3} \mathrm{H}\right] P A F$ to $P M N$. Studies presented in Fig. 1 indicate that PMN specifically bind $\left[{ }^{3} \mathrm{H}\right] \mathrm{PAF}$ at $4{ }^{\circ} \mathrm{C}$. This binding increased progressively over $\sim 40 \mathrm{~min}$; after $40 \mathrm{~min}$, apparent equilibrium occurred. Scatchard analysis of binding fit a tworeceptor model (Fig. 6, upper panel). Extrapolated values for $K_{\mathrm{d}}$ and number of binding sites per cell were: $0.2 \mathrm{nM}$ and 1,100 (high affinity receptors) and $200 \mathrm{nM}$ and 200,000 (low affinity receptors).

Location of binding sites. $4 \times 10^{8} \mathrm{PMN}$ in $7 \mathrm{ml}$ of relaxation buffer $\left(4^{\circ} \mathrm{C}\right)$ were disrupted and fractionated over Percoll gradients. 200- $\mu \mathrm{l}$ aliquots of each fraction were incubated at $4^{\circ} \mathrm{C}$ for 60 min with $200 \mathrm{pM}\left[{ }^{3} \mathrm{H}\right] \mathrm{PAF}, \pm 10 \mathrm{nM}$ PAF, and then assayed for binding by filtration techniques. The distribution of specific binding sites paralleled alkaline phosphatase activity (Fig. 7). In interpreting these results, we emphasize the following

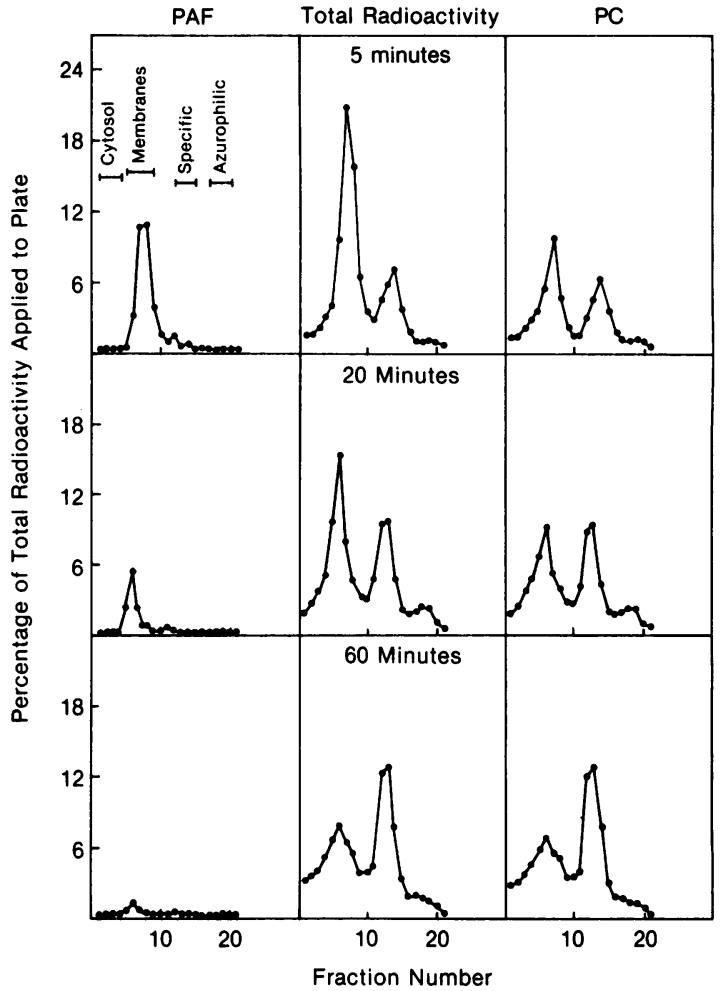

Figure 4. Subcellular distribution of radioactivity in PMN. Cells were incubated with $200 \mathrm{pM}\left[{ }^{3} \mathrm{H}\right] \mathrm{PAF}$ for 5 (upper panels), 20 (middle panels), or 60 (lower panels) min at $37^{\circ} \mathrm{C}$; disrupted; and centrifuged over Percoll gradients. Center panels give the total radioactivity in sequential fractions $(1.9 \mathrm{ml})$ from these gradients. Also shown are the amounts of radioactivity comigrating with PAF (left panels) and PC (right panels) standards on TLC. Results are reported as percentage of total applied radioactivity recovered in each fraction and are typical of studies done with three different donor cell preparations. Areas enriched with markers for cytosol, membranes, specific granules, and azurophilic granules are indicated.

points. First, Fig. 7 reports only specific binding (i.e., that inhibited by $10 \mathrm{nM}$ PAF). Second, nonspecific binding was fairly constant in all fractions $(\sim 1.5-2 \%$ of total added radioactivity). Third, filters trapped $>80 \%$ of applied membranes and granules but $<5 \%$ of applied cytosol, as determined by examining marker enzyme activities in prefiltered samples and filtrates. Finally, membranes closely sedimented with cell surface glycoproteins, as demonstrated with $\left[{ }^{3} \mathrm{H}\right]$ concanavalin A (Fig. 5). Thus, our technique measures only filterable specific binding sites. These sites appear strictly associated with cell surface and membrane markers. It seems unlikely that PMN granules contain appreciable numbers of $\left[{ }^{3} \mathrm{H}\right] \mathrm{PAF}$ receptors; soluble, nonfilterable receptors could be present in any portion of the gradients.

Characteristics of the membrane-associated receptor. $500 \mathrm{ml}$ of human blood were processed to obtain $8 \times 10^{8} \mathrm{PMN}$. The cells were suspended in $14 \mathrm{ml}$ of relaxative buffer, nitrogen cavitated, divided into two 7-ml aliquots, and separately fractionated over Percoll gradients. Membrane fractions 5-9 from both gradients were pooled $(\sim 18 \mathrm{ml})$, mixed with equal volumes of Percoll-dilution buffer, ultracentrifuged, and resuspended in $3.0 \mathrm{ml}$ of Hanks' buffer. The procedure afforded an $\sim 5.5$-fold increase in alkaline phosphatase and $\left[{ }^{3} \mathrm{H}\right] \mathrm{PAF}$ binding activities based on volumetric comparison. Thus, $\sim 90 \%$ of the applied binding 


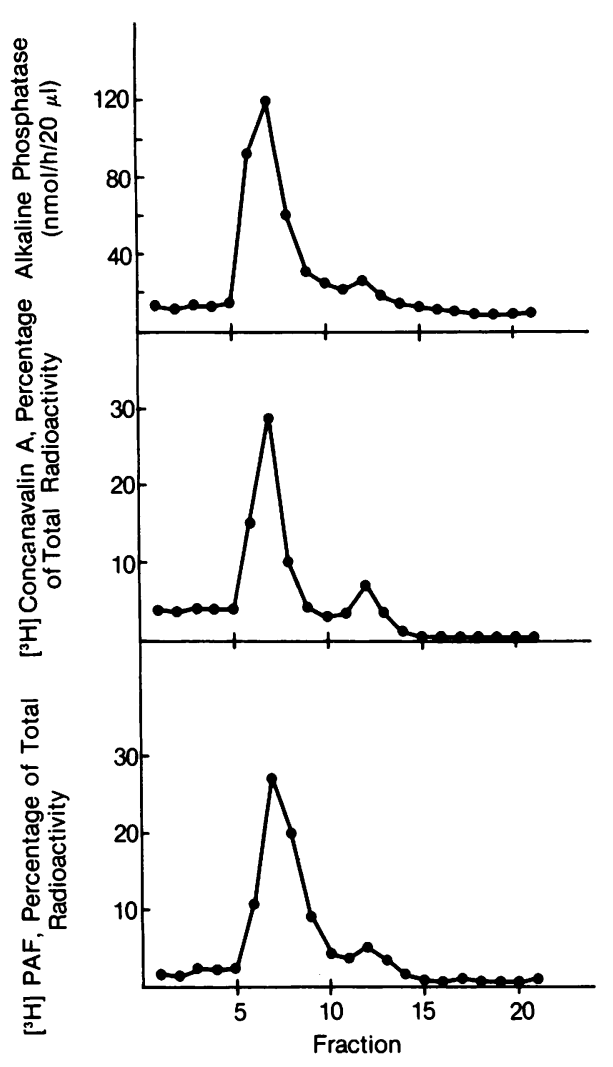

Figure 5. Distribution of subcellular markers and radioactivity in Percoll gradients of PMN. Cells were incubated with $\left[{ }^{3} \mathrm{H}\right]$ conconavalin $A$ for $20 \mathrm{~min}$ at $20^{\circ} \mathrm{C}$ (center panel) or [ $\left.{ }^{3} \mathrm{H}\right] \mathrm{PAF}(200 \mathrm{pM})$ for $60 \mathrm{~min}$ at $4^{\circ} \mathrm{C}$ (upper and lower panels). The cells were then disrupted and centrifuged over Percoll gradients. Results are reported as nanomoles $p$ nitrophenol phosphate produced per hour per $20 \mu$ l of fraction (upper panel) or percentage of total gradient radioactivity per fraction (center and lower panels). $>90 \%$ of radioactivity reported in the lower panel migrated with PAF standard on TLC. Results are typical of studies done with two different donor cells.

sites were recovered as particulate material. $\left[{ }^{3} \mathrm{H}\right] \mathrm{PAF}$ binding to the membrane preparations was performed at $4^{\circ} \mathrm{C}$ in a final volume of $1 \mathrm{ml}$ (Hanks' buffer containing calcium, magnesium and BSA). Specific binding was linearly related to the volume of membrane assayed between 10 and $160 \mu$ l. The total and specific radioactivity bound to $50-\mu \mathrm{l}$ aliquots of membrane increased progressively over $\mathbf{4 0} \mathrm{min}$ and leveled off thereafter. Results were quite similar to those found with intact cells (see Fig. 1). Addition of $10 \mathrm{nM}$ PAF to membranes preincubated with $20 \mathrm{pM}\left[{ }^{3} \mathrm{H}\right] \mathrm{PAF}$ for 60 min reduced binding by $33 \%$ within 10 min and $56 \%$ within 20 min. (Table I). Finally, specific binding was not appreciably altered by storing membranes at $4^{\circ} \mathrm{C}$ for $24 \mathrm{~h}$ or by pretreating PMN with $5 \mathrm{mM}$ diisopropylfluorophosphate $\left(4^{\circ} \mathrm{C} \times 20 \mathrm{~min}\right)$ and collecting cavitates into $50 \mathrm{mM}$ 2mercaptoethanol, $1 \mathrm{mM}$ phenylmethylsulfonyl fluoride, and 2 $\mathrm{mM}$ ethylenediaminetetraacetic acid. The membrane-associated receptor thus appears to be stable; with reference to its subcellar location, the receptor seems unaffected by the presence of bivalent cations or cellular proteases. Binding of $\left[{ }^{3} \mathrm{H}\right] \mathrm{PAF}$ to this receptor is readily saturated and at least partially reversible.

Scatchard analysis of membrane binding data (Fig. 6, lower panel) fit a two-receptor model: $K_{d}$ values for the high and low affinity binding sites were 0.2 and $500 \mathrm{nM}$, respectively. Based

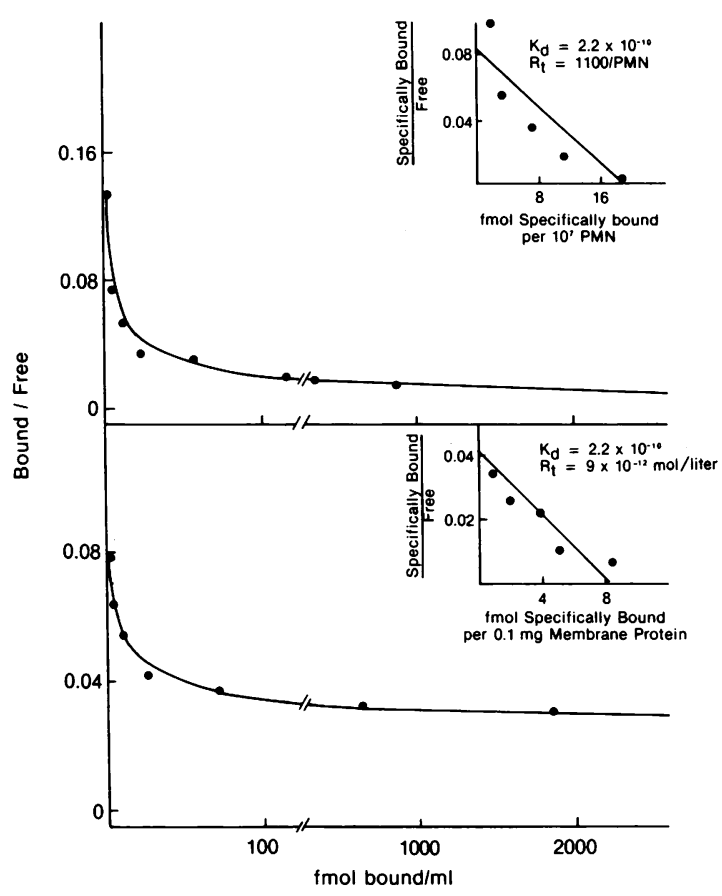

Figure 6. Binding data and Scatchard plots (insets) for $\left[{ }^{3} \mathrm{H}\right] \mathrm{PAF}$ binding to PMN (upper panel) or their ultracentrifuged membrane isolates (lower panel). Each point is the mean of 12 studies with different donor cell preparations and had an SEM of $<20 \%$.

on our measurements that $(a) 8 \times 10^{8}$ cavitated PMN should contain $8.8 \times 10^{11}$ high affinity receptors; $(b)$ centrifugal removal of undisrupted cells reduces alkaline phosphatase content by

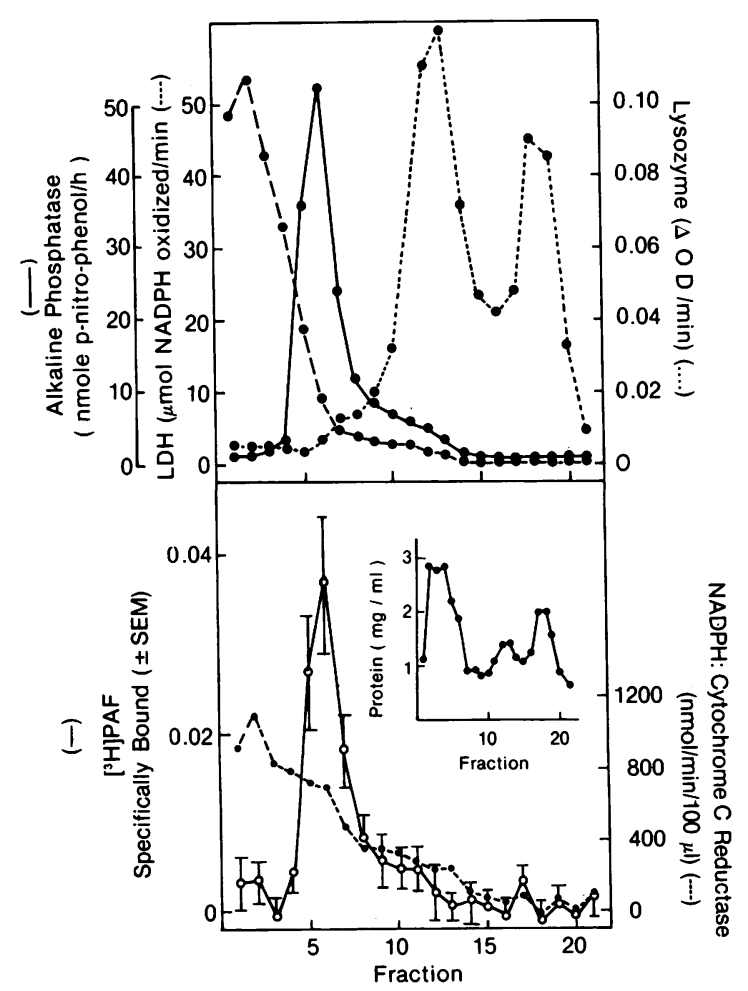

Figure 7. Subcellular markers and distribution of specific $\left[{ }^{3} \mathrm{H}\right] \mathrm{PAF}$ binding sites in Percoll gradient fractions of resting PMN. [ $\left.{ }^{3} \mathrm{H}\right] \mathrm{PAF}$ binding data are expressed as the mean for 12 studies on preparations from different donors. Protein assays (inset) were performed as in 43. 
Table I. Reversibility of $\left[{ }^{3} \mathrm{H}\right] P A F$ Binding to PMN Membranes*

\begin{tabular}{lll}
\hline & \multicolumn{2}{l}{ Time after adding $10 \mathrm{nM}$ PAF } \\
\cline { 2 - 3 } Condition & 10 & 20 \\
\hline & $\min$ & $\min$ \\
{$\left[{ }^{3} \mathrm{H}\right] \mathrm{PAF}+\mathrm{BSA}$} & $5.8 \pm 1.7 \ddagger$ & $6.3 \pm 1.7$ \\
{$\left[{ }^{3} \mathrm{H}\right] \mathrm{PAF}+\mathrm{PAF}$} & $3.9 \pm 0.6 \S$ & $2.8 \pm 0.7^{*}$ \\
\hline
\end{tabular}

* Isolated PMN membranes ( $50 \mu \mathrm{l}$ of a membrane preparation containing $71 \mu \mathrm{g}$ protein) were incubated $\left(4^{\circ} \mathrm{C}\right)$ with $20 \mathrm{pM}\left[{ }^{3} \mathrm{H}\right] \mathrm{PAF}$ in Hanks' buffer ( $900 \mu \mathrm{l}$ ) containing $1.4 \mathrm{mM} \mathrm{Ca}^{2+}, 0.7 \mathrm{mM} \mathrm{Mg}^{2+}$, and $62.5 \mu \mathrm{g} \mathrm{BSA}$. After $60 \mathrm{~min}$, suspensions were treated with $50 \mu \mathrm{l}$ of buffer containing $62.5 \mu \mathrm{g}$ of BSA or $10 \mathrm{nM}$ PAF plus $62.5 \mu \mathrm{g}$ BSA. Suspensions were then incubated for 10 or $20 \mathrm{~min}$ before filtering over GF/C filters and assayed for specific binding sites.

¥ Mean percentage $( \pm$ SEM) of total radiolabel specifically bound (see Methods) for four studies with different donor membrane preparations.

$\S$ Indicates values significantly lower $(P<0.02)$ than that observed with the addition of only BSA, based on paired Student's $t$ tests.

$41 \%$ (44); (c) $56 \%$ of alkaline phosphatase and $63 \%$ of $\left[{ }^{3} \mathrm{H}\right]$ concanavalin A applied to gradients are recovered in fractions 5-9 (44); and (d) $90 \%$ of ultracentrifuged alkaline phosphatase is recovered in pelleted membranes, we calculated a theoretical yield of $2.6 \times 10^{11}$ receptors. As derived from Scatchard analysis, we recovered $2.0 \times 10^{11}$ to $2.3 \times 10^{11}$ receptors. Most, if not all, high affinity receptors for $\left.{ }^{3} \mathrm{H}\right] \mathrm{PAF}$ thus are membrane associated. It seems unlikely that PMN contain an appreciable fraction of these receptors in a soluble state.

Binding of $63.2 \mathrm{pM}\left[{ }^{3} \mathrm{H}\right] \mathrm{PAF}$ to membranes was reduced by excess PAF, triethyl-PAF, and homocholine-PAF. Lyso-PAF did not inhibit binding at or below $632 \mathrm{nM}$. Potencies of these analogues in blocking membrane binding correlated with their respective potencies in stimulating PMN degranulation (Fig. 8).

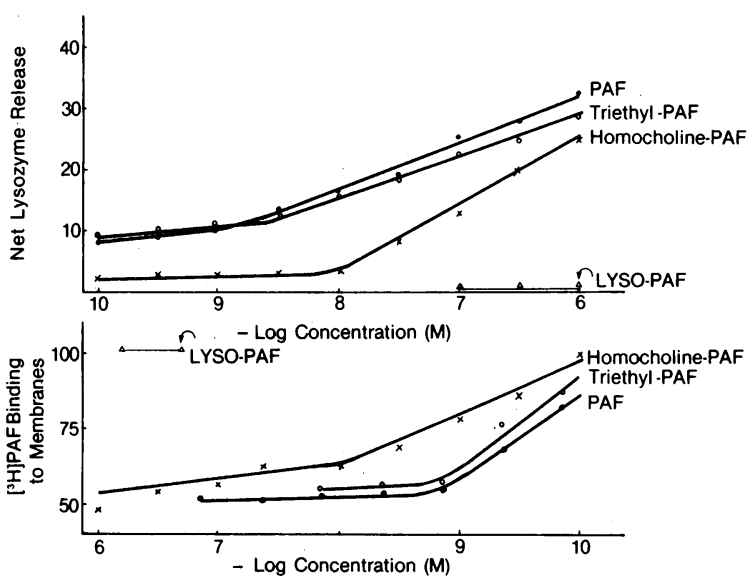

Figure 8. Potencies of four alkyl ether analogues in stimulating neutrophil degranulation (upper panel) or inhibiting $\left[{ }^{3} \mathrm{H}\right] \mathrm{PAF}(63.2 \mathrm{pM})$ binding to neutrophil membranes (lower panel). The degranulation responses seen with each of the three active analogues were significantly greater than that seen on unstimulated cells at all concentrations $\geqq 0.1$ nM $(P<0.05$, Student's paired $t$ test). Results are the mean of 10 studies on different donor cell preparations and report net enzyme release or $\left[{ }^{3} \mathrm{H}\right] \mathrm{PAF}$ bound to cells (as percentage of that bound by cells incubated only with $\left.\left[{ }^{3} \mathrm{H}\right] \mathrm{PAF}\right)$.
Within the limitations of these structure-activity analyses, membrane receptors appear involved in transmitting biological function.

\section{Discussion}

Hwang et al. (34) and Valone (48) found PAF receptors in membrane subfractions of platelets, tissues containing smooth muscle, rabbit PMN, and guinea pig PMN. We extend these studies to human PMN and refine this localization. Particulate, filterable receptors for $\left[{ }^{3} \mathrm{H}\right] \mathrm{PAF}$ were associated with cellular membranes enriched with alkaline phosphatase activity and $\left[{ }^{3} \mathrm{H}\right]$ concanavalin A-binding glycoproteins of the cell surface (Figs. 5 and 7). The distributions of these three parameters on Percoll gradients were almost identical to each other but quite distinct from markers for endoplasmic reticulum, cytosol, specific granules, and azurophilic granules. In a second series of complementary experiments, PMN were incubated with $\left[{ }^{3} \mathrm{H}\right] \mathrm{PAF}$ and then disrupted and fractionated. Again, intact radiolabel was limited to these same membrane fractions (Figs. 4 and 5). Failure to find intact $\left[{ }^{3} \mathrm{H}\right] \mathrm{PAF}$ outside these fractions implies that few, if any, receptors occur extramembranously. These results also agree with our calculated recovery (exceeding $80 \%$ ) of receptors in ultracentrifuged membrane isolates from resting PMN. We conclude that the bulk of PAF receptors reside within nongranule membranes. Presumably, these membranes are plasmalemma since they contain cell surface glycoproteins. However, the membrane preparations contained some NADPH: cytochrome $c$ reductase (Fig. 7). We therefore cannot exclude completely the possibility that some subcomponent of endoplasmic reticulum or other particulate subfraction (e.g., nuclear membrane, golgi, mitochondria, or oxyzomes) cosediments with plasmalemma and contains PAF receptors.

Membranous receptor binding of $\left[{ }^{3} \mathrm{H}\right] \mathrm{PAF}$ was readily saturated (Fig. 6, lower panel) and partially reversible (Table I). The data fit a two-receptor model with $K_{d}$ estimates for high and low affinity binding sites of 0.2 and $500 \mathrm{nM}$, respectively. Very similar results were obtained with whole cells (Fig. 6, upper panel). Furthermore, the PMN stimulating potencies of PAF, triethyl-PAF, homocholine-PAF, and lyso-PAF paralleled their relative efficacy in competing with $\left[{ }^{3} \mathrm{H}\right] \mathrm{PAF}$ for membrane binding sites. However, each bioactive analogue demonstrated 10 -fold greater potency in blocking $\left[{ }^{3} \mathrm{H}\right] \mathrm{PAF}$ binding to the high affinity receptors than in stimulating degranulation (Fig. 8, lower and upper panels, respectively). This difference need not indicate that the high affinity receptors fail to transmit the exocytoic actions of PAF. Degranulation responses to PAF require physiological temperatures and cytochalasin B; they are completed within 3 to $5 \mathrm{~min}$ after which the cells are selectively desensitized (31). Degranulation thus may reflect the rate of high affinity receptor occupancy, intracellular transducing events, and ligand metabolism (Fig. 3). These factors would tend to reduce the ligand's biological potencies without influencing its efficacy in binding assays performed at $4^{\circ} \mathrm{C}$. We therefore make no conclusions about the relative roles of the high and low affinity receptors in transducing degranulation. Rather, the data in Fig. 8 are interpreted only as indicating a close relationship of four structural analogues in activating PMN and binding to both high and low affinity receptors: the identified membranous binding sites appear functionally relevant.

Previous studies have established that PMN sequentially deacetylate and then transacylate $\operatorname{PAF}(16,17)$. We find that this 
metabolism is strictly temperature dependent: it does not occur at $4^{\circ} \mathrm{C}$ (Fig. 2), whereas it proceeds quantitatively and with remarkable rapidity at $37^{\circ} \mathrm{C}$ (Fig. 3). In addition, excess PAF enhanced the conversion of $\left.{ }^{3} \mathrm{H}\right] \mathrm{PAF}$ to acylated product (compare the upper and lower panels of Fig. 3). These results are relevant to interpretations of previous studies. For instance, working at $4^{\circ} \mathrm{C}$, we found 1,100 high affinity PAF receptors per PMN; at $37^{\circ} \mathrm{C}$, Valone and Goetzl (35) found $5 \times 10^{6}$ receptors. This discrepancy may be due, in part, to ligand metabolism at the more physiological temperature. Likewise, studies quantitating whole cell PAF production (4-15) measure net ligand accumulation. Actual PAF production may be much greater than accumulation if, as seen in Fig. 3, cells can metabolize $>75 \%$ of PAF within minutes.

$\left[{ }^{3} \mathrm{H}\right] \mathrm{PAF}$ metabolism appeared to take place within PMN membranes since intact ligand occurred only in membranecontaining subfractions and acylated metabolite initially accumulated in these same sites (Fig. 4). The results, however, cannot exclude a possibility that some $\left[{ }^{3} \mathrm{H}\right] \mathrm{PAF}$ is instantaneously metabolized elsewhere. In separate studies (49), we have found acetylhydrase, the enzyme deacetylating PAF, principally in cytosol, and acyl transferase, the transacylating enzyme, in PMN membranes. Ligand may be sequentially attacked by cytosolic and membrane-bound enzymes as it sits on the inner leaf of plasmalemma. In any case, following acylation, the radiolabeled product then appears to be shuttled to other membranes including specific granules and, to a lesser extent, azurophilic granules. The elevated radioactivity seen in cytosol (fractions 14 or 5 in the lower panels of Fig. 4) may reflect transcytosolic movement (perhaps mediated by PC-specific exchange proteins [50]) or, alternatively, an accumulation of acylated product in endoplasmic reticulum, which contaminates cytosolic fractions (Fig. 7). It is interesting to note that acylated PAF may be an important source of metabolizable arachidonic acid, as well as PAF $(16,17,51,52)$. Granule-bound phospholipids, then, may be crucial for the production of bioactive lipids.

In conclusion, the studies reported here support a clearer view of the way in which cells handle PAF. The ligand first enters cell surface membranes to interact with specific, functionally relevant receptors that are themselves integral membrane components. Alternatively, the intramembranous ligand is progressively converted to acylated product and transferred to granule subfractions. These two distinct fates appear competitive: receptor binding may sequester ligand from cytosolic hydrolase and thereby keep it intact for as much as 60 min (Fig. 4); on the other hand, metabolism may decrease the availability of ligand for receptor binding and indirectly result in its removal to granular membranes.

\section{Acknowledgments}

Thanks to Nan Hartman for preparing this manuscript.

This work was supported by National Institutes of Health grants HL27799, HL-26257, HL-26818, HL-28491, and AI-17287.

\section{References}

1. Hanahan, D. J., C. A. Demopoulas, J. Liehr, and R. N. Pinckard. 1980. Identification of platelet activating factor isolated from rabbit basophils as acetyl glyceryl ether phosphorylcholine. J. Biol. Chem. 255: 5514-5516.

2. Polonsky, J., M. Tence, P. Varenne, B. C. Das, J. Lunel, and J.
Benveniste. 1980. Release of 1-O-alkylglyceryl 3-phosphorylcholine- $O$ deacetyl platelet-activating factor, from leukocytes: Chemical ionization mass spectrometry of phospholipids. Proc. Natl. Acad. Sci. USA. 77: 7019-7923.

3. Blank, M. L., F. Synder, L. W. Byers, B. Brooks, and E. E. Muirhead. 1979. Antihypertensive activity of an alkyl ether analog of phosphatidylcholine. Biochem. Biophys. Res. Commun. 90:1194-1200.

4. Chap, H., G. Mauco, M. F. Simon, J. Benveniste, and L. DousteBlazy. 1981. Biosynthetic labelling of platelet activating factor from radioactive acetate by stimulated platelets. Nature (Lond.). 289:312-324.

5. Benveniste, J., M. Chignard, J. P. Le Couedic, and B. B. Vargaftig. 1982. Biosynthesis of platelet-activating factor (Paf-acether) II. involvement of phospholipase $\mathrm{A}_{2}$ in the formation of PAF-acether and lysoPAF-acether from rabbit platelets. Thromb. Res. 25:375-385.

6. Camussi, G., M. Aglietta, R. Coda, F. Bussolino, W. Piacibello, and C. Tetta. 1980. Release of platelet-activating factor (PAF) and histamine. II. The cellular origin of human PAF: monocytes, polymorphonuclear neutrophils and basophils. Immunology. 42:191-199.

7. Betz, S. J., and P. M. Henson. 1980. Production and release of platelet-activating factor (PAF); dissociation from degranulation and superoxide production in the human neutrophil. J. Immunol. 125:27562763.

8. Mueller, H. W., J. T. O'Flaherty, and R. L. Wykle. 1983. Biosynthesis of platelet activating factor in rabbit polymorphonuclear neutrophils. J. Biol. Chem. 258:6213-6218.

9. Lee, T.-C., D. J. Lenihan, B. Malone, L. L. Roddy, and S. I. Wasserman. 1984. Increased biosynthesis of platelet-activating factor in activated human eosinophils. J. Biol. Chem. 259:5526-5530.

10. Mueller, H. W., J. T. O'Flaherty, and R. L. Wykle. 1984. The molecular species distribution of platelet-activating factor synthesized by rabbit and human neutrophils. J. Biol. Chem. 259:14554-14559.

11. Mencia-Huerta, J.-M., R. Roubin, J.-L. Morgat, and J. Benveniste. 1982. Biosynthesis of platelet-activating factor (PAF-acether). III. Formation of PAF-acether from synthetic substrates by stimulated murine macrophages. J. Immunol. 129:804-808.

12. Albert, D. H., and F. Synder. 1983. Biosynthesis of 1-alkyl-2acetyl-sn-glycero-3-phosphocholine (platelet-activating factor) from 1alkyl-2-acyl-sn-glycero-3-phosphocholine by rat alveolar macrophages. J. Biol. Chem. 258:97-102.

13. Blank, M. L., T.-C. Lee, V. Fitzgerald, and F. Snyder. 1981. A specific acetylhydrolase for 1-alkyl-2-acetyl-sn-glycero-3-phosphocholine (a hypotensive and platelet-activating lipid). J. Biol. Chem. 256:175178.

14. Prescott, S. M., G. A. Zimmerman, and T. M. McIntyre. 1984. Human endothelial cells in culture produce platelet-activating factor (1-alkyl-2-acetyl-sn-glycero-3-phosphocholine) when stimulated with thrombin. Proc. Natl. Acad. Sci. USA. 81:3534-3538.

15. Camussi, G., M. Aglietta, F. Malavasi, C. Tetta, W. Piacibello, F. Sanavio, and F. Bussolino. 1983. The release of platelet-activating factor from human endothelial cells in culture. J. Immunol. 131:23972403.

16. Chilton, F. H., J. T. O'Flaherty, J. M. Ellis, C. L. Swendsen, and R. L. Wykle. 1983. Metabolic fate of platelet-activating factor in neutrophils. J. Biol. Chem. 258:6357-6361.

17. Chilton, F. H., J. T. O'Flaherty, J. M. Ellis, C. L. Swendsen, and R. L. Wykle. 1983. Selective acylation of lyso platelet activating factor by arachidonate in human neutrophils. J. Biol. Chem. 258:7268-7271.

18. Kramer, R. M., G. M. Patton, C. R. Pritzker, and D. Deykin. 1984. Metabolism of platelet-activating factor in human platelets: Transacylase-mediated synthesis of $1-O$-alkyl-2-arachidonyl-sn-glycero3-phosphocholine. J. Biol. Chem. 259:13316-13320.

19. Pieroni, G., and D. J. Hanahan. 1983. Metabolic behavior of acetyl glyceryl ether phosphorylcholine on interaction with rabbit platelets. Arch. Biochem. Biophys. 224:485-493.

20. Touqui, L., C. Jacquemin, and B. B. Vargaftig. 1983. Conversion of ${ }^{3} \mathrm{H}-\mathrm{PAF}$ acether by rabbit platelets is independent from aggregation: evidences for a novel metabolite. Biochem. Biophys. Res. Commun. 110: 890-893. 
21. Siraganian, R. P., and A. G. Osler. 1971. Destruction of rabbit platelets in the allergic response of sensitized leukocytes. I. Demonstration of a fluid phase intermediate. J. Immunol. 106:1244-1251.

22. O'Flaherty, J. T., C. H. Miller, J. C. Lewis, R. L. Wykle, D. A. Bass, C. E. McCall, M. Waite, and L. R. DeChatelet. 1981. Neutrophil responses to platelet-activating factor. Inflammation. 5:193-201.

23. Handley, D. A., C. M. Arbeeny, M. L. Lee, R. G. Van Valen, and R. N. Saunders. 1984. Effect of platelet activating factor on endothelial permeability to plasma macromolecules. Immunopharmacology. 8:137-142.

24. Hartung, H.-P. 1983. Acetyl glyceryl ether phosphorylcholine (platelet-activating factor) mediates heightened metabolic activity in macrophages. Studies on PGE, $\mathrm{TXB}_{2}$ and $\mathrm{O}_{2}$ production, spreading, and the influence of calmodulin-inhibitor W-7. Fed. Eur. Biochem. Soc. Lett. 160:209-212.

25. Stimler, N. P., C. M. Bloor, T. E. Hugli, R. L. Wykle, C. E. McCall, and J. T. O'Flaherty. 1981. Anaphylactic actions of plateletactivating factor. Am. J. Pathol. 105:64-69.

26. Stimler, N. P., and J. T. O'Flaherty. 1983. Spasmogenic properties of platelet-activating factor: evidence for a direct mechanism in the contractile response of pulmonary tissues. Am. J. Pathol. 113:75-84.

27. McManus, L. M., D. J. Hanahan, C. A. Demopoulos, and R. N. Pinckard. 1980. Pathobiology of the intravenous infusion of acetyl glyceryl ether phosphorylcholine (AGEPC), a synthetic platelet-activating factor (PAF), in the rabbit. J. Immunol. 124:2919-2924.

28. Sánchez-Crespo, A., F. Alonso, P. Iñarrea, V. Alvarez, and J. Egido. 1982. Vascular actions of synthetic PAF-acether (A synthetic platelet-activating factor) in the rat: evidence for a platelet independent mechanism. Immunopharmacology. 4:173-185.

29. Humphrey, D. M., L. M. McManus, D. J. Hanahan, and R. N. Pinckard. 1984. Morphologic basis of increased vascular permeability induced by acetyl glyceryl ether phosphorylcholine. Lab. Invest. 50:1625.

30. O'Flaherty, J. T., R. L. Wykle, C. H. Miller, J. C. Lewis, M. Waite, D. A. Bass, C. E. McCall, and L. R. Dechatelet. 1980. 1-O-alkyl$s n$-glyceryl-3-phosphorylcholines. A novel class of neutrophil stimulants. Am. J. Pathol. 102:70-78.

31. O'Flaherty, J. T., C. J. Lees, C. H. Miller, C. E. McCall, J. C. Lewis, S. H. Love, and R. L. Wykle. 1981. Selective desensitization of neutrophils: further studies with 1-O-alkyl-sn-glycero-3-phosphocholine analogues. J. Immunol. 127:731-737.

32. Wykle, R. L., C. H. Miller, J. C. Lewis, J. D. Schmitt, J. A. Smith, J. R. Surles, C. Piantadosi, and J. T. O'Flaherty. 1981. Stereospecific activity of 1-O-alkyl-2-O-acetyl-sn-glycero-3-phosphocholine and comparison of analogs in the degranulation of platelets and neutrophils. Biochem. Biophys. Res. Commun. 4:1651-1658.

33. Valone, F. H., E. Coles, V. R. Reinhold, and E. J. Goetzl. 1982. Specific binding of phospholipid platelet-activating factor by human platelets. J. Immunol. 129:1637-1641.

34. Hwang, S.-B., C.-s. C. Lee, M. J. Cheah, and T. Y. Shen. 1983. Specific receptor sites for 1-O-alkyl-2-O-acetyl-sn-glycero-3-phosphocholine (platelet activating factor) on rabbit platelet and guinea pig smooth muscle membranes. Biochemistry. 22:4756-4763.

35. Valone, F. H., and E. J. Goetzl. 1983. Specific binding by human polymorphonuclear leukocytes of the immunological mediator1-O-hexadecyl-octadecyl-2-acetyl-sn-glycero-3-phosphorylcholine. Immunology. 48:141-148.

36. Chesney, C. M., D. D. Pifer, and K. M. Huch. 1985. Densensi- tization of human platelets by platelet activating factor. Biochem. Biophys. Res. Commun. 127:24-30.

37. Shen, T. Y., S.-b. Hwang, M. N. Chang, T. W. Doebber, M.-h. T. Lam, M. S. Wu, X. Wang, G. Q. Han, and R. Z. Li. 1985. Characterization of a platelet-activating factor receptor antagonist isolated from haifenteng (Piper futokadsura): specific inhibition of in vitro and in vivo platelet-activating factor-induced effects. Proc. Natl. Acad. Sci. USA. 82:672-676.

38. Valone, F. H. 1985. Inhibition of binding of the platelet-activating factor AGEPC to platelets by the AGEPC analog rac-3(N-n-octadecylcarbamoyloxy)-2-methoxypropyl 2-thiazolioethyl phosphate (CV-3988). Biochem. Biophys. Res. Commun. 126:502-508.

39. Kornecki, E., Y. H. Ehrlich, and R. H. Lenox. 1984. Plateletactivating factor-induced aggregation of human platelets specifically inhibited by triazolobenzodiazepines. Science (Wash. DC). 226:1454-1456.

40. Borregaard, N., J. M. Heiple, E. R. Simons, and R. A. Clark. 1983. Subcellular localization of the b-cytochrome component of the human neutrophil microbicidal oxidase: translocation during activation. J. Cell Biol. 97:52-61.

41. Surles, J. R., R. L. Wykle, J. T. O’Flaherty, W. L. Salzer, M. J. Thomas, F. Snyder, and C. Piantadosi. 1985. Facile synthesis of plateletactivating factor and racemic analogues containing unsaturation in the sn-1-alkyl chain. J. Med. Chem. 28:73-78.

42. Wyrick, S. D., J. S. McClanahan, R. L. Wykle, and J. T. O'Flaherty. 1985. Tritiated hexadecyl platelet activating factor (PAF). J. Label. Compounds Radiopharm. 22:1169-1174.

43. Nishihira, J., and J. T. O'Flaherty. 1985. Phorbol myristate acetate receptors in human polymorphonuclear neutrophils. J. Immunol. 135: 3439-3447.

44. O'Flaherty, J. T., S. Kosfeld, and J. Nishihira. 1986. Binding and metabolism of leukotriene $B_{4}$ by neutrophils and their subcellular organelles. J. Cell. Physiol. 126:359-370.

45. Lefitzki, A. Quantitative aspects of ligand binding to receptors. In Cellular Receptors for Hormones and Neurotransmitters. D. Schulster and A. Letvitzki, editors. John Wiley \& Sons, New York. 9-28.

46. Hollenberg, M. D. 1978. Receptor models and the action of neurotransmitters and hormones. In Neurotransmitter Receptor Binding. H. I. Yamamura, editor. Raven Press, New York. 13-39.

47. Shak, S., and I. M. Goldstein. 1985. Leukotriene $B_{4} \omega$-hydroxylase in human polymorphonuclear leukocytes. Partial purification and identification as a cytochrome P-450. J. Clin. Invest. 76:1218-1228.

48. Valone, F. H. 1984. Isolation of a platelet membrane protein which binds the platelet-activating factor 1-O-hexadecyl-2-acetyl-snglycero-3-phosphorylcholine: Immunology. 52:169-174.

49. Wykle, R. L., S. C. Olson, and J. T. O'Flaherty. 1986. Biochemical pathways of platelet-activating factor synthesis and breakdown. Adv. Inflam. Res. In press.

50. Lumb, R. J., G. L. Pool, D. G. Bubace, M. L. Blank, and F. Snyder. 1983. Spontaneous and protein-catalyzed transfer of 1-alkyl-2acetyl-sn-glycero-3-phosphocholine (platelet-activating factor) between phospholipid bilayers. Biochim. Biophys. Acta. 750:217-222.

51. Swendsen, C. L., J. M. Ellis, F. H. Chilton III, J. T. O'Flaherty, and R. L. Wykle. 1983. 1-O-alkyl-2-acyl-sn-glycero-3-phosphocholine: a novel source of arachidonic acid in neutrophils stimulated by the calcium ionophore A23187. Biochem. Biophys. Res. Commun. 113:72-79.

52. Purdon, A. D., and J. B. Smith. 1985. Turnover of arachidonic acid in the major diacyl and ether phospholipids of human platelets. $J$. Biol. Chem. 260:12700-12704. 